\title{
Research on the Contemporary Situation of University's Ideological and Political Education and the Corresponding Countermeasures under the New Circumstances
}

\author{
Jiaqian Zhang \\ Department of Social Sciences, Binzhou Polytechnic, \\ Shandong,256600, China
}

\begin{abstract}
In this paper, we conduct research on the contemporary situation of university ideological and the political education and the corresponding countermeasures under the new circumstances. Traditional ideological and political education the subjective one-sided emphasis on the authority of educators and initiative of neglect or even deny the education object and make the education effect is weakened with the past our wrong understanding of inculcating theory of Marxism. In the process of ideological and political education, the education object is that people are not content, thus to achieve education goal, must abandon treat education object of property thinking and humanistic thinking, in the process of infusion based on the ideological reality of the education object, respect the subjective initiative of the education object, realize the ideological indoctrination and the effective combination of meet the demand of the education object.
\end{abstract}

Keywords- Ideological and Political, Countermeasures, New Circumstances, Situation.

\section{Introduction}

With the popularity of values diversity, new media and the reforms of the higher education in recent years, the effect of the innovation of the ideological and the political education method system reform faces severe challenges. Under the condition of the new era, using the correct ideological and political education method is very important. Method of ideological and political education is an important means of education to realize the communication between subject as is the important link between the education content and education goal, completes the education method of the contemporary college students innovation for education management plays an important role in guiding [1-3].

Innovation of ideological and basic political education method, it is necessary to pay attention to students' self-education, self-supervision, intensify the management of self-education method, make the students from passive to accept into the active practice need to keep up with the social situation, understand the characteristics of the new education object and take effective methods to carry out the targeted education to ensure effectiveness with the education. From a psychological point of view, the most distinct symbol of the group is the group members in psychological contact and the interaction. Groups can meet a variety of psychological needs of its members group psychological impact on the individual has a strong role and is an important factor of ideological and political education cannot be ignored that could be summarized as the listed aspects. (1) When personal behavior is in line with group norms, group will get encouragement and the support, to further strengthen their own behavior. People engaged in an activity, a job, because get help or advice of the rest of the group, and enhance their confidence. When in trouble, especially when people receive timely group in the help of others, will strengthen your courage to overcome difficulties. In a group, individual potential will 
get play, strength. (2) Clustering is an important characteristic of human beings. In the long process of human development, people realize that any individual in a harsh natural environment and complex social environment is small it is difficult to resist the attack and damage, only form a group, and didn't have the strength that can defeat the environment to develop ourselves. (3) When the group achievement, its members will cheer when failure group, and its members and frustrated. Individual always put the individual gain and loss, the credit with group closely linked with the credit of the gain and loss.

Daily life shows the process of the socialization of ideological and political education, ideological and political education is the characteristics and the objective requirement of the modern society. The field of ideological and political education into daily life, really close to the life, close to the people, reality, in order to better promotes the socialization of individual to make the ideological and political education to meet the need of daily life, promoting the modernization of the ideological and political education to realize the transformation. Therefore, the ideological and basic political education must discard the traditional education mode, from life, close to the daily life of education method and the content, the ideological and political education and daily life science organically linked, prompting with ideology of scientific theory into people's spiritual pursuit, outside into the conscious action of the people. The figure one demonstrates framework of university ideological and political education.

- ideological parties: parties based on a particular set of social, economic, and political beliefs

- single-issue parties: parties focused on only one public-policy issue

- economic protest parties: parties whose members are united by anger over economic hard times and dislike for the major parties

- splinter parties: parties that have split off from one of the major parties; often focused on a single popular leader

Figure 1. The Framework of University's Ideological and Political Education
In this paper, we conduct research on the contemporary situation of university's ideological and the political education and the corresponding countermeasures under the new circumstances. Traditional ideological and political education has the knowledge, tools and idealized signatures, and daily life for common people to highlight certain practicality, subjectivity and reality. Ideological and political education should be highly integrated with the daily life, but in the practical education, often ignored the ideological and political education is the most basic daily life's apartment, due to the lack of the ideological and political education into daily life, in the process of ideological and political education into daily life faces many difficulties. In the later sections, we will discuss the related issues.

\section{Our Proposed Perspective}

The College Students' Mental Features. College students in a developing mature finalize the design phase of the outlook on life. From the psychological point of view, they are in a very important turning point in psychological development, psychological health problems has been the social attention. In terms of young college students, mental health is that it can fully coordinate their cognition, emotion, lines, to achieve good social adaptation, and be able to fully tap their own potential. From the point of the view of development, psychological health is a lifetime of life subject, and showed a strong stage, in the stage of youth life contradiction and the special focus, particularly prominent, particularly sharp and especially typical. There are many reasons for the influence of contemporary college students' mental health both the social factors also has the school factors both the influence of family factors, and the student individual factors [4-5].

From the point of view of the individual development, college students are in the general phase of adolescent life stage of development, and youth is late. This is a period of rapid 
changes, a short-term preparation phase into adulthood that is the qualitative leap, individual socialization process is a fast developing period of intense conflict and personality. Adolescence on personality development is a central issue for the pursuit of self-identity, establish self-identity and this is makes one different from any the other individual. The problem began in infancy, peaked at puberty self-looking for problems, because of physical, cognitive, social and emotional development reached a peak [6].

College students' individual internalization level, by cultivating basic ability of self-analysis and self-evaluation, conscious self-education and self-evaluation ability consciously in the practice of the self-education and self-improvement, constantly find themselves on the personality and behavior, the advantages and disadvantages of and self-discipline and adjustment, make oneself of the personality tendency of excellent, they can better solve the problem of self-identity, promote the development of physical and mental health. Therefore, college should help young students establish positive correct world outlook, the outlook on the life, values, improve self-analysis ability, strengthen self-discipline, creating an ideal self as the finalized goal and achievement.

The China's New Situation. The 21st century, with the profound changes of international and the domestic situation of subject, object and carrier of propaganda and ideological work in colleges and the universities with the external environment and made a profound impact on both, propaganda and ideological work in colleges and universities are faced with the economic development into the new normal, plural value orientation is more complex, and against the mainstream and traditional social mood rise and a series of new challenges.

Higher education appears the contradictions and problems need to solve, should stand in the point of view of science for further optimization and improvement of subjective intention will not be able to rely on the wild speculation, beyond the basis of theoretical and practical conditions. The most proper way, it should be combined with the overall trend of the national development and according to the current situation of national development of higher education in the contradiction between adjusted and solved, thus forming the new strategic decisions [7-8].

Under the new situation, education management system in colleges and universities in China in the year of change of advancing with the times, constantly into the society, people's communication, more and more has the characteristics of contribution and fairness. Teaching is no longer a single city a lot of students will also be able to enjoy education in the poor areas. Different levels of institutions of the higher learning can actually teach a high level of education, so we need to institutions of the higher learning education system widely in different areas to meet the demand of the economic development, set up the own level. Improve the management level of institutions of the higher learning, the building under the condition of the social economy rapid development of higher education system.

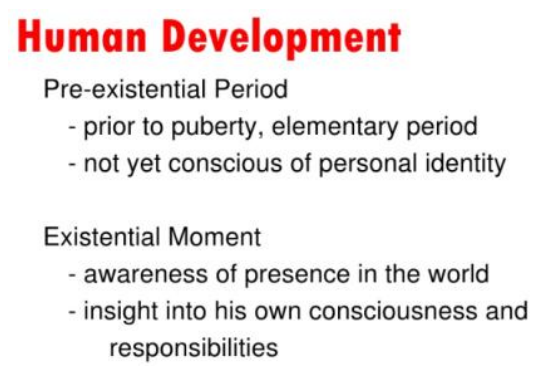

Figure 2. The Principles of the Human Development Pattern

\section{The Education Reform in Colleges.} Teachers for schools in basic education group, and play an important role in the teaching. They are the leading role of teaching activities as is the main force of cultivating high-quality innovative talents to satisfy the needs of society. Teachers' work enthusiasm, creativity and initiative are directly related to the degree of level and school-running benefit of school as a whole. To 
activate the enthusiasm of university teachers' teaching is to strengthen the teacher troop construction, the key to improve the quality of teaching and cultivating innovative talents. To do this, the most important measures to establish an effective incentive mechanism. From the perspective of management psychology, we believe that the needs of teachers are the foundation of implementing incentive mechanism. School administrators to make incentive teacher's way to be successful and we must first understand characteristics of the professional teachers and demand, and grasp the behavior rule, thus influence and guidance teachers' behavior to achieve organizational goals.

In the education teaching reform practice, should be a research innovation will be the educational reform, to cultivate students and the combination of innovation pattern, let the students play a role, especially graduate students in the education teaching reform actively participate in, the teacher wants to inspire guide students to give full play to their talents, explore their potential, and let them practice in practice, fully listen to the opinions of students in the education teaching reform and the suggestion, so as to timely find the key problem of the educational reform, teachers and students together difficult, so that the outcome of the innovation has real significance. In front of the educational reform project fully listen to opinions and suggestions of students. In the educational reform subject clear before, let the teachers and students in a variety of communication, and graduate students class cadre exchange, sometimes arrange open graduate seminars, students listen to opinions and suggestions of teaching and educational reform, especially the master constrained problem to improve the quality of teaching, the main factors of teachers and students to discuss the problems [9].

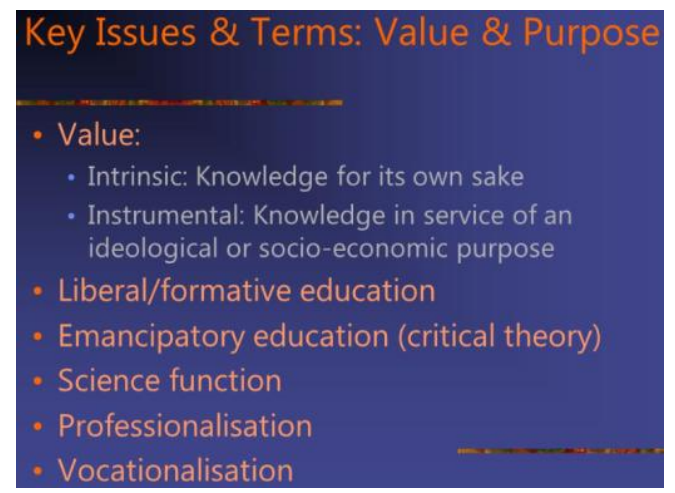

Figure 3. The Principles of the Education Reform and Targets

The Ideological and Political Education. College students' ideological and the political education needs innovation in combination with the present situation of the education development, related principles and rules, timely adjust principle and the mechanism of education, the development towards a healthy direction. It is only through a variety of methods to make ideological and political education content into the heart, brain as can achieve substantial results of ideological and political education. Teachers as the main body of education, education on the knowledge directly into students, and students as the object of classroom education factors, passive accept knowledge learning process.

The improvement of the ideological and political education to improve the quality of the graduate students has important significance to the development of the graduate education is facing diversified social competition, the enterprise and the state of talent main methods and means of screening. Due to the continuous development of graduate education in our country, formed pluralistic values, which require a mentor in graduate student daily learning work directed by correct way. Mentor as a guide for graduate studies forward power, in the process of graduate student thought political education work plays an important role. Historical development and evolution from the concept of ideological and political education, we understand political work, ideological work, the ideological and political work, such as concept, is 
people before appellation in practice the basic concept of ideological and the political education, sometimes they are used as the concept of the same concept or the same level.

Also see should be to which in theory and practice is the difference between each other, understand the difference, we can make the more accurate theoretical knowledge better grasp the content of work in practice. From the logic of Marxist analysis of the relationship between man and society, society is made up of people, so there is no away from people and isolation of social existence. People and can be embodied as the class, class and class of the molecules. Value subject after be brought up to value relationships from a single social value also extend to individual value, etc. Therefore, the ideological and political education from social function understanding deepens to the value of a man.

\section{Conclusion}

In this paper, we conduct research on the contemporary situation of the university ideological and the political education and the corresponding countermeasures under the new circumstances. College ideological and political education work is a systems engineering, in order to get the good education effect, need to fully mobilize and play the role of ideological and political education carrier. So, we need to carefully analyze the characteristics of the carrier of the ideological and political education at colleges and universities, in order to better pinpoint location, clear responsibilities, foster strengths and circumvent weaknesses, complement each other, and then on to grasp the new characteristics of ideological and political education carrier in the new period, on the basis of expansion of ideological and political education carrier new space in the new environment and the new features, so as to get a better education effect. Our research suggests the new idea on the corresponding issues, and in the future, we will review more research to optimize our perspective.

\section{References}

[1] Li, Yunzhi, and Baoyi Zhang. "Research on Application of New Media in Expanding Approaches for College Network Ideological and Political Education." 2015 International Conference on Education Technology and Economic Management. Atlantis Press, 2015.

[2] Yuan, Li. "Research on the Effectiveness of College Ideological and Political Education from Information Perspective." The Science Education Article Collects 1 (2015): 008.

[3] Zhang, Liping. "Analysis on Penetrative Effects of New Media on Ideological and Political Education of Universities and Colleges." Open Journal of Social Sciences 3.12 (2015): 207.

[4] Keisch, Deborah M., and Tim Scott. "US Education Reform and the Maintenance of White Supremacy through Structural Violence." Landscapes of Violence 3.3 (2015): 6.

[5] Furong, D. E. N. G. "A Thought on Strengthening Value Education in the Ideological and Political Course to College Students: Taking the "Ideological and Moral Cultivation and Law Basis" Course as an Example." Canadian Social Science 11.6 (2015): 39-42.

[6] Strandbrink, Peter. "Fair and cloudy weathers of tolerance in civic and religious education in northern Europe." Education, Citizenship and Social Justice 10.1 (2015): 3-20.

[7] Elfert, Maren. "UNESCO, the Faure report, the Delors report, and the political utopia of lifelong learning." European Journal of Education 50.1 (2015): 88-100.

[8] Nienhusser, H. Kenny. "Undocumented Immigrants and Higher Education Policy: The Policymaking Environment of New 
York State." The Review of Higher Education 38.2 (2015).

[9] Wiehe, Elsa. "The New Political Economy of Urban Education: Neoliberalism, Race, and the Right to the City, by Pauline Lipman." Rethinking Marxism 27.1 (2015): 140-143. 